\title{
Documenting Caddo Ceramic Sherd and Lithic Collections from Prehistoric Sites at Lake Bob Sandlin
}

Timothy K. Perttula

Heritage Research Center, Stephen F. Austin State University

Mark Walters

Heritage Research Center, Stephen F. Austin State University

Bo Nelson

Heritage Research Center, Stephen F. Austin State University

Follow this and additional works at: https://scholarworks.sfasu.edu/ita

Part of the American Material Culture Commons, Archaeological Anthropology Commons, Environmental Studies Commons, Other American Studies Commons, Other Arts and Humanities Commons, Other History of Art, Architecture, and Archaeology Commons, and the United States History Commons

Tell us how this article helped you.

This Article is brought to you for free and open access by the Center for Regional Heritage Research at SFA ScholarWorks. It has been accepted for inclusion in Index of Texas Archaeology: Open Access Gray Literature from the Lone Star State by an authorized editor of SFA ScholarWorks. For more information, please contact cdsscholarworks@sfasu.edu. 
Documenting Caddo Ceramic Sherd and Lithic Collections from Prehistoric Sites at Lake Bob Sandlin

\section{Creative Commons License \\ (c) (1) (9)}

This work is licensed under a Creative Commons Attribution-NonCommercial 4.0 International License 


\title{
Documenting Caddo Ceramic Sherd and Lithic Collections from Prehistoric Sites at Lake Bob Sandlin
}

\author{
Timothy K. Perttula, Mark Walters, and Bo Nelson
}

\section{INTRODUCTION}

Following on the heels of a previous archaeological effort where we documented collections of ceramic and lithic artifacts from a wide variety of prehistoric archaeological sites along the shoreline at Lake Bob Sandlin (Nelson and Perttula 2003a), this article puts on record the range of prehistoric ceramic and lithic artifacts in collections we recently documented from four sites at the lake in Camp and Titus counties, Texas. One of the four sites has been previously reported in the Caddo archaeological literature, but the other three have not.

\section{New Island (41CP22)}

The New Island site has been described by Thurmond (1990:53) as having Late Archaic (ca. 3000-500 B.C.) and Late Caddo (ca. A.D. 14001680) components. The Late Caddo component is apparently associated with at least eight burialshaped looter pits.

The collection from the New Island site has 81 sherds, 68 of which are plain (Table 1). Utility wares $(n=10)$ include sherds from punctated, incised-punctated, incised, and brushed vessels, while the fine wares are composed of three engraved sherds. The occurrence of brushed vessels as well as one body sherd with a carelessly engraved circular element (Figure 1a; see also Thurmond 1990:Figure 6d) suggests that this ceramic sherd assemblage dates to the earlier part of the Late Caddo period, although a larger sample of decorated sherds should be collected from this site to be more definitive about its temporal and cultural affiliations.

The lithic artifacts from the New Island site include chipped stone tools $(\mathrm{n}=2)$, lithic debris $(n=62)$, and one quartzite core. The chipped stone tools are a Gary dart point and a quartzite biface tip. The Gary point in the documented collection hints at some use of the New Island site during the
Woodland period (ca. 500 B.C. to A.D. 800), when this style of contracting stemmed dart point was in common use by Woodland hunters.

\section{South of Milligan (41CP490)}

The South of Milligan site is near the Milligan Point site (41CP276). That site has extensive mid$19^{\text {th }}$ century Anglo-American farmstead archaeological deposits, as well as evidence of occasional use in the Late Archaic and Early Paleoindian periods (Nelson and Perttula 2003a:26-34). The South of Milligan site, however, was primarily occupied during Late Caddo Titus phase times (ca. A.D. 14301680), as evidenced by a substantial sample of Titus phase decorated utility ware and fine ware sherds.

A total of 520 ceramic sherds are in the documented collection from the South of Milligan site, including 314 plain sherds and 206 decorated sherds (Table 2). The plain to decorated sherd ratio (P/DR) is only 1.52 , compared to $\mathrm{P} / \mathrm{DR}$ ratios that range between 3.24 and 3.75 for the Early Caddo ceramic assemblages from the Cedar Island (41TX891) and TXU Park (41TT892) sites (see below). Based on the proportion of rim sherds among the different wares, utility ware vessels are most common in the ceramic assemblage $(51 \%)$, followed by fine wares $(32 \%)$ and plain wares (16\%). Among the decorated sherds, including both rim and body sherds, almost $83 \%$ of the decorated sherds in the assemblage are from utility wares. The fine wares-both engraved and red-slipped vessels - comprise the remainder of the decorated sherds (Table 2).

The utility ware sherds from the South of Milligan site are from brushed jars, as $66 \%$ of the rim and body sherds have brushing, either as the sole decoration or in combination with incised, incised-appliqued, punctated, and appliqued decorations (see Table 2). These sherds are from Bullard Brushed as well as Pease Brushed-Incised jars, and either the vessel was brushed on both the rim and the 
Table 1. Ceramic sherds from the New Island site documented collection.

\begin{tabular}{lccc}
\hline Decorative method/elements & Rim sherd & Body sherd & Base sherd \\
\hline Plain & 2 & 65 & 1
\end{tabular}

\section{Utility Ware}

Tool punctated rows

Fingernail punctated rows

Incised-tool punctated row

Horizontal incised lines

Parallel incised lines

Parallel brushed

\begin{tabular}{lll}
- & 2 & - \\
- & 1 & - \\
- & 1 & - \\
1 & - & - \\
- & 3 & - \\
- & 2 & - \\
& & \\
1 & & - \\
- & - & - \\
- & 1 & - \\
4 & 1 & 1 \\
\hline
\end{tabular}

Fine Ware

Opposed engraved lines

Horizontal engraved (bottle)

Circular engraved

Totals

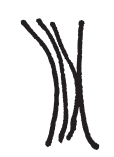

a

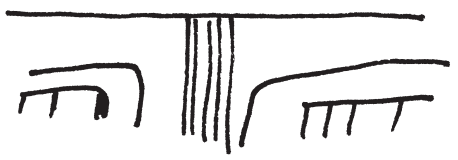

C

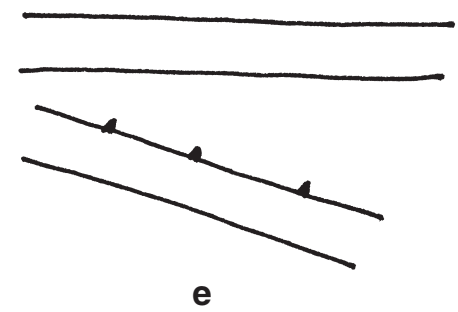

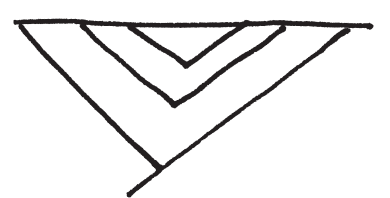

b

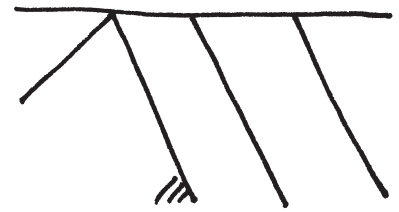

d

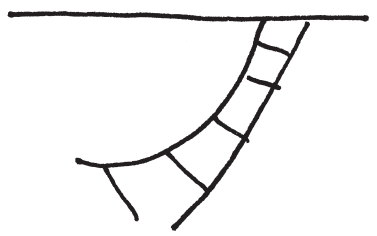

f

Figure 1. Selected decorative elements on sherds from the New Island and South of Milligan sites: a, carelessly engraved circle; b, opposed incised lines; c, Ripley Engraved scroll motif; d, Ripley Engraved, probable continuous scroll motif; e, Ripley Engraved scroll motif with triangular tick marks; f, hatched curvilinear zone. Provenience: a, New Island site (41CP22); b-f, South of Milligan site (41CP490). 
body (as with Bullard Brushed), or else horizontal brushing was applied to the rim and vertical brushing was applied to the body in panels demarcated by vertical appliqued fillets or appliqued ridges (as with Pease Brushed-Incised). Vessels with simple vertical appliqued fillets or ridges on the body are probably from either misnamed McKinney Plain vessels (Suhm and Jelks 1962:97)—which are not plain—or from La Rue Neck Banded jars (Suhm and Jelks 1962:93). Tool punctated rims may be from Mockingbird Punctated jars, a recently recognized Titus phase utility ware with horizontal rows of tool punctations on the rim of the vessel; vessel bodies (based on whole vessels) tend to be plain or have simple vertical appliqued ridges/fillets as decoration. Incised jars of the Maydelle Incised type have opposed (see Figure 1b) as well as cross-hatched incised lines on the rim.

The fine wares from the South of Milligan site are apparently primarily from Ripley Engraved carinated bowls, based both on the recognizable elements of engraved scrolls characteristic of the type (see Thurmond 1990:Figure 6) along with other decorative elements that occur in the scroll fill zones or as supplemental elements to the larger motif (see Figure 1c and Table 2). These would include such elements as the hatched corners of engraved triangles (see Figure 1d), central scroll lines, triangular tick marks on scroll lines (see Figure 1e), or small triangular cross-hatched fill elements. One body sherd from a Wilder Engraved bottle has a widened or "swelled" curvilinear excised area on the arm of a scroll (cf. Suhm and Jelks 1962:155).

Other engraved sherds have hatched curvilinear zones (see Figure 1f) or have horizontal engraved lines on the rim (see Table 2). These latter sherds are probably from the upper panel of Ripley Engraved compound bowls, jars, or ollas, as these typically have 2-3 widely-spaced horizontal engraved lines on the upper panel or rim, and a scroll-related motif on the lower panel or vessel body (see Turner 1978:Figure 24a-e). Also included in the fine wares from the South of Milligan site is a trailed sherd, possibly from a Keno Trailed vessel, and two plain red-slipped body sherds. Red-slipped sherds are a consistent feature of a number of Titus phase ceramic assemblages in the general Lake Bob Sandlin area (e.g., Nelson and Perttula 2003b; Perttula 2005).

Prehistoric lithic artifacts in the collections from the South of Milligan site include 49 pieces of lithic debris and chunks (42 quartzite and seven petrified wood), as well as three quartzite cores, and a quartzite biface fragment. Projectile points from the site include three Late Caddo points-a quartzite Maud arrow point, a quartzite Bassett arrow point, and a Perdiz quartzite arrow point - three Woodland period style quartzite Gary points (var. Camden $[\mathrm{n}=1]$ and var. LeFlore $[\mathrm{n}=2])$, one quartzite Yarbrough dart point, a Middle to Late Archaic style with a flat but expanding stem dart point base made from a non-local grayish-white chert, and a quartzite dart point tip. These tools suggest more intensive use of the South of Milligan site for hunting during the Woodland and Late Caddo periods.

\section{Cedar Island (41TT891)}

The Cedar Island site lies between two other known sites along the Lake Bob Sandlin shoreline: New Hope (41FK107) and Collins Pt. (41TT757). The New Hope site was occupied during Late Paleoindian (ca. 10,500-10,000 years B.P.), Late Archaic, and Woodland period times, but the principal settlement was during the Early Caddo period (Nelson and Perttula 2003a:43-44). The Collins Pt. site has a Middle Caddo settlement (Nelson and Perttula 2003a:50).

There are 250 ceramic sherds in the documented Cedar Island collection, including 191 plain sherds and 59 decorated sherds (Table 3). The plain to decorated sherd ratio is 3.24 . Approximately $70 \%$ of the decorated sherds (but only $43 \%$ of the decorated rim sherds) are from utility wares, with the remainder (including 57\% of the decorated rim sherds) coming from engraved and red-slipped fine ware vessels.

The predominance of punctated decorations in the utility wares $(61 \%)$, along with incised-punctated (9.8\%) and incised (29\%) vessels-combined with the absence of any brushed, brushed-punctated, or appliqued vessels - indicate that the prehistoric Caddo occupation at the Cedar Island site dates before ca. A.D. 1200. After that date, brushed utility wares are ubiquitous on Caddo sites along this stretch of the Big Cypress Creek basin. The Early Caddo occupation at the Cedar Island site is further substantiated by the identification of two Holly Fine Engraved body sherds in the collection (see Table 3), including one with an excised triangle element (cf. Suhm and Jelks 1962:Plates 39 and 40).

In addition to the ceramic vessel sherds, the Cedar Island site collection has a clay coil fragment (evidence of on-site vessel manufacture) and a single piece of daub. 
Table 2. Ceramic sherds from the South of Milligan site documented collection.

\begin{tabular}{lccc}
\hline Decorative method/elements & Rim sherd & Body sherd & Base sherd \\
\hline Plain & 6 & 288 & 20
\end{tabular}

Utility Ware

Parallel brushed

Overlapping brushed

Opposed brushed

Vertical brushed

Horizontal brushed

Brushed-incised elements

Brushed-incised-appliqued elements

Parallel brushed-tool punctated

Tool punctated rows

Tool punctated, free

Horizontal and diagonal tool punctated rows

Incised-punctated elements

Horizontal incised lines

Cross-hatched incised lines

Opposed incised lines

Parallel incised lines

Straight incised line

Neck banded

Appliqued nodes

Appliqued fillets

Appliqued fillets-parallel brushed

Appliqued fillets-incised line

Appliqued ridges

Appliqued ridges-parallel brushed

Appliqued ridge-tool punctated rows

Subtotals

$\begin{array}{cc}- & 88 \\ - & 4 \\ - & 2 \\ - & 1 \\ 5 & - \\ - & 6 \\ - & 1 \\ - & 1 \\ 5 & 5 \\ - & 3 \\ & \\ 1 & - \\ 1 & - \\ 1 & - \\ - & 2 \\ 1 & 4 \\ - & 15 \\ - & 2 \\ 3 & - \\ 1 & - \\ - & 1 \\ - & 1 \\ - & 1 \\ - & 4 \\ - & 5 \\ 1 & 1 \\ 19 & 152\end{array}$

\section{Fine Ware}

Ripley Engraved scrolls

Ripley Engraved elements

Wilder Engraved elements

Cross-hatched fill elements

Horizontal engraved lines

Curvilinear engraved lines

Semi-circular engraved lines

Parallel engraved lines

Hatched engraved triangle

straight engraved line

Trailed line

Lip notched

Red-slipped

Subtotals

$\begin{array}{lcc}3 & 3 & - \\ 2 & - & - \\ - & 1 & - \\ - & 3 & - \\ 5 & 1 & - \\ 1 & 1 & - \\ - & 2 & - \\ - & 4 & - \\ - & 1 & - \\ - & 4 & - \\ - & 1 & - \\ 1 & - & - \\ - & 2 & - \\ 12 & 23 & - \\ 37 & 463 & 20\end{array}$


Table 3. Ceramic sherds from the Cedar Island site documented collection.

\begin{tabular}{lccc}
\hline Decorative method/elements & Rim sherd & Body sherd & Base sherd \\
\hline Plain & 1 & 178 & 12 \\
Utility Ware & & & \\
Tool punctated, free & - & 11 & - \\
Fingernail punctated, free & - & 13 & - \\
Diagonal linear punctated rows & 1 & - & - \\
Incised triangles filled with & & & - \\
$\quad$ tool punctates & - & 2 & - \\
Horizontal incised lines and & 1 & - & - \\
$\quad$ associated fingernail punctated row & - & 1 & - \\
Incised line-fingernail punctated & 1 & - & - \\
Diagonal incised lines & - & 2 & - \\
Straight incised lines & - & 6 & - \\
Parallel incised lines & - & 3 & \\
Opposed incised lines & 3 & & \\
$\quad$ Subtotal & & &
\end{tabular}

\section{Fine Ware}

Interior engraved line

Straight engraved lines

Parallel engraved lines

Horizontal engraved lines

Diagonal engraved lines

Cross-hatched engraved lines

Holly Fine Engraved el.

Excised triangle, cf. Holly

Fine Engraved

Red-slipped

Subtotal
Totals

Lithic artifacts in the Cedar Island documented collection include a quartzite Late Archaic dart point with a long parallel stem and a flat base, a quartzite biface tool fragment, 40 pieces of lithic debris, one core, and two pieces of fire-cracked rock.

\section{TXU Park (41TT892)}

The TXU Park site, based on the documented ceramic sherds to be discussed shortly, apparently has a substantial and virtually single component pre-A.D. 1200 Early Caddo archaeological deposit. A total of 542 ceramic sherds are in the collections from the site, including plain rim, body, and base sherds $(\mathrm{n}=428,79 \%)$, utility ware rim and body sherds ( $n=63,11.6 \%)$, and fine ware rim and body sherds $(n=51,9.6 \%)$ (Table 4). With respect to the proportion of rims in the assemblage, plain ware vessels are common (39.5\% of the rims), as are fine ware $(32.6 \%)$ and utility ware $(28 \%)$ vessels in roughly equal measure.

The P/DR ratio at the TXU Park site is 3.75, not much different than that from the Early Caddo ceramic assemblage from the Cedar Island site $(\mathrm{P} / \mathrm{DR}=3.24)$, but substantially different from the $\mathrm{P} / \mathrm{DR}$ of 1.52 for the Late Caddo Titus phase ceramic 
Table 4. Ceramic sherds from the TXU Park site documented collection.

\begin{tabular}{lccc}
\hline Decorative method/elements & Rim sherd & Body sherd & Base sherd \\
\hline Plain & 17 & 389 & 22
\end{tabular}

\section{Utility Ware}

Parallel brushed

Diagonal tool punctated row

Tool punctated, random

Tool punctated rows

Linear punctated row

Fingernail punctated, random

Cane punctated rows

Incised-punctated elements

Cross-hatched incised lines

Diagonal incised lines

Horizontal incised lines

Rectilinear incised lines

Parallel incised lines

Straight incised lines
Subtotal

17

$\begin{array}{lc}- & 2 \\ 1 & - \\ - & 17 \\ 1 & 2 \\ - & 1 \\ - & 11 \\ 1 & - \\ 3 & 3 \\ - & 3 \\ 3 & - \\ 3 & 1 \\ - & 1 \\ - & 8 \\ - & 2 \\ 12 & 51\end{array}$

\section{Fine Ware}

Holly Fine Engraved

Diagonal engraved lines

Horizontal engraved lines

Opposed engraved lines

Semi-circle engraved lines

Vertical-horizontal engraved lines

Parallel engraved lines

Straight engraved lines

Curvilinear engraved lines

Red-slipped

$\frac{\text { Subtotal }}{\text { Totals }}$

12

\begin{tabular}{lcc}
6 & 5 & - \\
1 & - & - \\
6 & 1 & - \\
- & 2 & - \\
- & 2 & - \\
1 & - & - \\
- & 14 & - \\
- & 4 & - \\
- & 8 & - \\
- & 1 & - \\
14 & 37 & 22 \\
\hline 43 & 477 &
\end{tabular}

assemblage at the South of Milligan site. Clearly, the earlier Caddo ceramic assemblages from prehistoric Caddo sites in the Lake Bob Sandlin area of the Big Cypress Creek basin have much higher proportion of plain wares among the entire ceramic sherd assemblages, as well as a propensity to decorate vessels more often on only the rim, rather than on both the rim and the body. The latter became much more common after ca. A.D. 1200 with the advent of the use of brushing decoration on exterior vessel surfaces.
Among the engraved fine wares from the TXU Park site, the principal ceramic type is Holly Fine Engraved, with six rim sherds and five body sherds (Figure 2a-f, h) among the small sample of fine wares. One thick cambered rim (see Suhm and Jelks 1962:77) has a very wide lip with an excised triangle atop the lip (Figure 2a). The majority of these are carinated bowls that have finely engraved sets of opposed diagonal or opposed curvilinear engraved lines divided by triangular excised areas; one bottle 


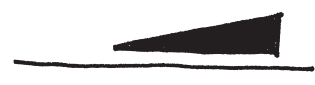

a

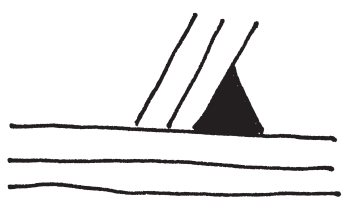

d

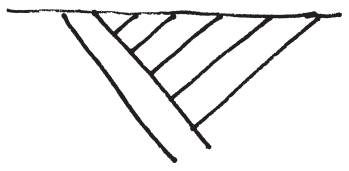

g

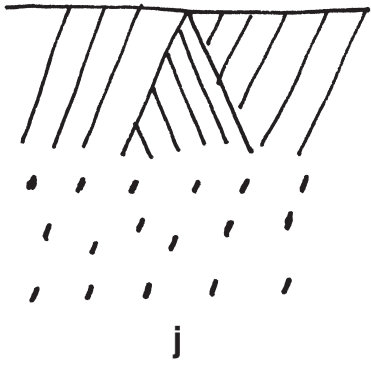

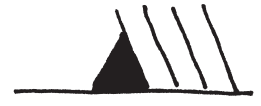

b

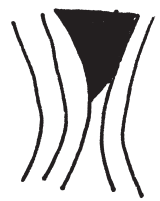

e

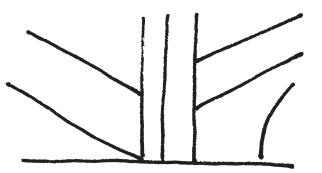

h

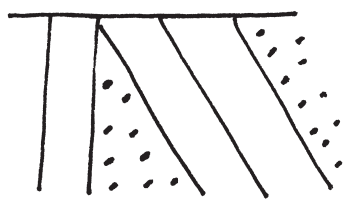

$\mathbf{k}$

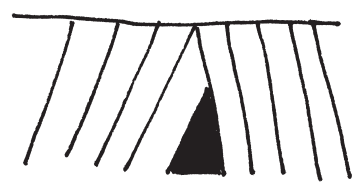

C

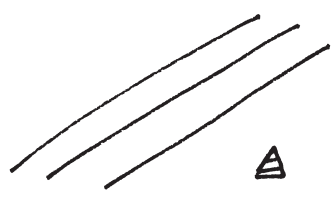

f

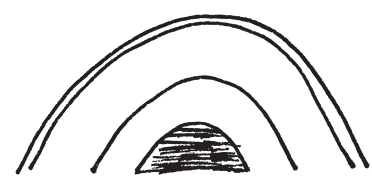

i

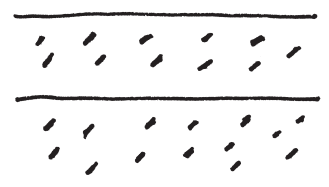

I

Figure 2. Selected decorative elements/motifs on sherds from the TXU Park site: a, Holly Fine Engraved, engraved element on cambered rim; b-f, h, Holly Fine Engraved rim and body sherds; g, diagonal opposed fine engraved lines, probably Holly Fine Engraved; i, semi-circular engraved lines; j-1, incised-punctated rim sherds.

sherd (Figure 2f) has a set of fine parallel engraved lines adjacent to a small hatched triangle element. A body sherd has sets of both finely engraved vertical and opposed diagonal engraved lines (Figure $2 \mathrm{~h}$ ), although there is no apparent associated excised triangle. Another probable Holly Fine Engraved rim at the site has opposed sets of finely engraved diagonal lines, but again no apparent associated excised triangle element (Figure 2g).

The other engraved type at the TXU Park site that can be confidently identified in the ceramic assemblage is Hickory Engraved $(n=7)$, which are 
rims and body sherds from bowls and carinated bowls with horizontal engraved lines encircling the vessel (Suhm and Jelks 1962:Plate 36). There are also several engraved sherds from carinated bowls that apparently have sets of semi-circular engraved lines (see Figure 2i). In one instance, the innermost semi-circle has been excised; in another sherd, a semi-circle engraved element has a single vertical engraved line within it. One red-slipped body sherd comprises $2 \%$ of the fine wares (see Table 4).

The utility ware sherds are from vessels decorated with punctations ( $54 \%$ of the utility ware sherds, see Table 4), incised lines (33\%), or with both incised lines and punctations (9.5\%); the two other utility ware sherds are two brushed body sherds, likely not temporally related to the early Caddo ceramic assemblage recognized at the TXU Park site. The punctated sherds are from both the rim and body of jars, with rows of punctations (tool and cane) on the rim, and more randomly or freely placed punctations (mainly tool and fingernail) on the vessel body. No Weches Fingernail Impressed sherds were noted in the TXU Park site utility wares. Incised-punctated rim sherds include one from a Dunkin Incised vessel with sets of opposed hachured incised lines on the rim and tool punctated rows on the body (see Figure 2j); a possible Pennington Punctated Incised vessel with vertical and diagonal sets of incised lines and triangular areas between filled with tool punctations (see Figure 2k); and horizontal incised lines dividing up freely placed tool punctations (see Figure 2l). Three incised-punctated body sherds have one or two straight incised lines adjacent to an area filled with tool punctations.

The incised rim sherds from the site have either horizontal (probably from Davis or Kiam Incised vessels) or diagonal (Dunkin Incised) incised decorations. Body sherds with cross-hatched lines may well be from Dunkin Incised carinated bowls (Suhm and Jelks 1962:Plate 19i).

The lithic artifacts from the TXU Park site include lithic debris $(\mathrm{n}=74)$, several chipped stone tools $(n=7)$, and ground stone tools $(n=3)$. The lithic debris is comprised of a single quartzite core, pieces of quartzite $(n=48,65 \%)$, petrified wood $(n=9$, $12 \%)$, and various kinds of chert $(n=16,22 \%)$ flakes and chips from tool manufacturing activities. The chert lithic debris includes red $(\mathrm{n}=1)$, grayish-brown $(n=2)$, dark brown $(n=3)$, gray $(n=8)$, brown $(n=1)$, and $\tan (n=1)$ colors; the red and tan cherts are likely from local stream gravel sources, but the other cherts are from unknown non-local sources.
The chipped stone tools in the TXU Park site collection include the following projectile points: a quartzite Gary, var. Camden dart point of Woodland period age, an Edgewood dart point made from a non-local dark brown chert, and a light gray chert (also probably from a non-local source) Alba arrow point. Other chipped stone tools are two thin novaculite and quartzite biface fragments, a thick quartzite biface fragment, and a petrified wood gouge.

The ground stone tools in the TXU Park collection include three celts in various stages of manufacture. One is the poll end of a broken celt made from a Ouachita Mountains graywacke, and the other two are greenish-gray quartzitic sandstone celt preforms. The preforms have been roughly shaped by flaking, cortex remains on both pieces, and the celts were never polished to bring them to their complete form.

\section{SUMMARY}

The ceramic and lithic artifact collections that we have documented from the New Island (41CP22), South of Milligan (41CP490), Cedar Island (41TT891), and TXU Park (41TT892) sites at Lake Bob Sandlin first provide information on their temporal and spatial attributes, and form part of the large database of sites known in some detail from the Lake Bob Sandlin area (e.g., Nelson and Perttula 2003a, 2003b; Thurmond 1990). All four of the sites are situated on landforms (now partly or regularly inundated) that occur in proximity to Big Cypress Creek and its once wide floodplain, and one site (New Island) is situated at the confluence of Big Cypress Creek with its principal tributary in this part of the basin, Brushy Creek.

Two of the sites, Cedar Island and TXU Park, were apparently occupied primarily in Early Caddo times, sometime prior to A.D. 1200. Sites of this age are not common at Lake Bob Sandlin (Perttula and Nelson 2003:Table 1), and those that are known are widely spaced across the lake area (Perttula and Nelson 2003:Figure 7), although they are found primarily along Big Cypress Creek and Brushy Creek, rather than in upland or valley margin areas. The most distinguishing characteristic of the recovered ceramic vessel sherds from the Cedar Island and TXU Park sites is the regular occurrence of Holly Fine Engraved and Hickory Engraved sherds in the fine wares, along with an assortment of utility wares with simple incised, punctated, and incised- 
punctated rim and/or body decorations. Plain wares are also abundant in these pre-A.D. 1200 Caddo ceramic assemblages. Associated lithic artifacts include an Alba point, celts made from Ouachita Mountains lithic raw materials, and an assortment of lithic debris from tool manufacture utilizing primarily local sources of quartzite.

The other two sites, New Island and South of Milligan, primarily have Late Caddo Titus phase occupations. Late Caddo sites are predominant at Lake Bob Sandlin (Perttula and Nelson 2003:Table 1 and Figure 9) among all the prehistoric Caddo sites. These sites occur in several clusters that appear to represent parts of contemporaneous small communities or villages established along Big Cypress Creek and Brushy Creek, and in upland/valley margin settings. The Titus phase ceramics from the two sites are dominated by Ripley Engraved fine wares and brushed, appliqued, punctated, and incised utility ware jars from types such as Bullard Brushed, Pease Brushed-Incised, McKinney Plain, Mockingbird Punctated, and Maydelle Incised. Brushed wares are a particularly noticeable feature of the Titus phase utility wares in this part of the Big Cypress Creek basin. At the South of Milligan site, there are quartzite Maud, Perdiz, and Bassett style arrow points that were made and used during the Titus phase occupation there.

\section{REFERENCES CITED}

Nelson, Bo and Timothy K. Perttula

2003a Archeological Survey along the Lake Bob Sandlin Shoreline, Camp, Franklin, and Titus Counties, Texas. Report of Investigations No. 46. Archeological and Environmental Consultants, LLC, Austin.

2003b Archeological Investigations of the Underwood Site (41CP230): A Titus Phase Settlement along Big Cypress Creek in Camp County, Texas. Journal of Northeast Texas Archaeology 17:1-61.

Perttula, Timothy K. and Bo Nelson

2003 Temporal and Spatial Patterns in the Prehistoric Settlement of the Lake Bob Sandlin Area, Big Cypress Creek Basin, Northeastern Texas. Caddoan Archeology Journal 13(2):28-35.

Suhm, Dee Ann and Edward B. Jelks (editors)

1962 Handbook of Texas Archeology: Type Descriptions. Texas Archeological Society Special Publication 1 and Texas Memorial Museum Bulletin 4, The University of Texas at Austin.

Thurmond, J. Peter

1990 Archeology of the Cypress Creek Drainage Basin, Northeastern Texas and Northwestern Louisiana. Studies in Archeology 5. Texas Archeological Research Laboratory, The University of Texas at Austin.

Turner, Robert L., Jr.

1978 The Tuck Carpenter Site and Its Relation to Other Sites Within the Titus Focus. Bulletin of the Texas Archeological Society 49:1-110. 